Received: 09.04.2015.

Original scientific work

UDK: 76-057.874

\title{
ATTITUDES OF PRIMARY SCHOOL PUPILS ABOUT PRINTMAKING ${ }^{1}$
}

\author{
Letricija Linardić \\ Academy of Applied Arts University of Rijeka \\ letricija.linardic@apuri.hr
}

\begin{abstract}
This study shows results of an action research conducted on a sample of 170 third-, fifthand eighth-grade pupils, in three Croatian primary schools, during one school semester. The aims were to examine the pupils' attitudes about printmaking, particularly relating to their ability to identify printmaking concepts and the regularity of in-class delivery of different types of printmaking techniques, and to examine pupils' activity and attitudes about the importance and position of printmaking in the contemporary social context.

The research was based on pupils' experiences in printmaking classes in schools. The data were gathered by using a specially designed questionnaire, which was administered to pupils before and after the action research. The results demonstrated the following: the pupils' identification of printmaking concepts, techniques and different types of print increased after the second measuring. In addition, pupils' activity in bringing materials to classes also increased, as well as their awareness of the importance of applied and "artistic" graphics, as compared with the first measuring.
\end{abstract}

Keywords: visual arts classes, pupils' attitudes, pupils' activity, applied graphics, printmaking techniques

\section{Introduction}

In accordance with the national curriculum (HNOS, National curriculum, 2006), visual arts education, all artistic areas (sculpting, painting, printmaking and drawing) have to be equally distributed throughout the classes, in order to allow for a proportionate acquisition of general and specific knowledge, competence and skills. A balanced inclusion of the above stated areas into classes positively affects students' cognitive, psycho-motor and emotional development. Visual art classes in primary school stimulate and develop many forms of knowledge and competence, such as creativity and intellectual skills. In addition, they stimulate communication and expressiveness and positively affect motivation, behavior, concentration and self-esteem (Watts, 2005). Finally, visual arts classes stimulate identification of visual art objects, improve visual perception and memory and develop abstract thinking (Andrilović i Čudina, 1985).

Each field of art, owing to the characteristics of art techniques and procedures, as well as different working materials, helps pupils develop specific skills and competencies. Printmaking, for instance, allows for the acquisition of specific knowledge and skills, which, due to the specific nature of art techniques and processes, are not covered by classes in sculpting, painting or drawing.

\footnotetext{
${ }^{1}$ Prikazano istraživanje dio je opsežnijeg istraživanja provedenog u sklopu doktorske disertacije
} 
In printmaking classes, pupils acquire terminology and conceptual knowledge both in visual arts and in printmaking. Knowledge gained in regular printmaking classes can be divided into two aspects: general knowledge of visual arts language and specific knowledge of concepts from the so-called artistic graphics and applied graphics ${ }^{2}$. These are related to the specifics of each printmaking technique (including printmaking procedures, materials and tools). In addition, pupils gain knowledge in graphic design, as well as knowledge in history and culture of printmaking, both in traditional and contemporary contexts.

In accordance with the tendencies of modern teaching, the acquisition of knowledge, competencies and skills should be accomplished through an increase in pupils' activity and reduction in teachers' activity. Therefore, practical classes are essential for such forms of teaching. In practical classes, which include the teaching of printmaking techniques and motifs, as well as an introduction to visual art concepts, pupils individually and actively gain operative and permanent knowledge, skills and competencies. Through the means of expression offered by each printmaking technique, pupils can form and upgrade their knowledge of concepts and work on their skills. Further, printmaking classes are designed in such a way that they proportionally combine sensory, practical, reflective and theoretical elements. This is in line with Dewey's concept of education, which promotes the acquisition of knowledge based on experience (Jelavić, 1998). Practical experience is very important for development of pupils' cognitive processes. It is a vital part of learning, since pupils' motor skills support the development of thinking, and thinking, in turn, reinforces motors skills. In other words, thinking and motors skills are in a constant interaction. Practical classes that rely on the use of all senses positively affect pupils' whole development (Montessori, 2003). Classes arranged in such way increase pupils' activity, help them integrate their knowledge and skills and encourage them to conduct independent research in fields of printmaking.

By learning specific technical procedures relating to particular printmaking techniques, which are offered in practical classes, pupils develop a number of general and specific skills that are closely related to the previously acquired conceptual knowledge. For instance, while performing printmaking procedures, pupils enhance their fine and gross motor skills (eye-hand coordination, the precision on copying the sketch onto the matrix, precision in treating the surface, skillfulness and precision in printing process). Furthermore, while working on the mirror image and transferring the image onto the matrix, which requires a reversed logic of thinking, students develop their memory, logic and abstract reasoning. Finally, in practical classes students develop planning and organizing skills since they need to prepare their desktops and create working plans.

Printmaking classes encourage student activities towards development of senses (visual, auditory and tactile). This may stimulate students to conduct independent research and increase their motivation for broadening their experiences (Hannaford, 2005).

Classes in printmaking also develop creativity, since they include activities that increase students' perception of visual art concepts and ideas. They also enable them to search for multiple solutions to a task, which improves divergent thinking. Students find different printmaking procedures very interesting, which increases their motivation and enhances the development of creativity (Planinšek, 2000, Brešan, 2004). Development of creative skills in students is utterly important since this process affects creativity output in other fields of life and improves creative thinking in general (Karlavaris and Kraguljac, 1981).

A variety of printmaking techniques, with their specific procedures and numerous possibilities of expression, offers the teachers an entire range of themes that motivate students to come up with and formalize their own ideas. Moreover, this variety may encourage them to generate many possible solutions and develop visual forms of communication offered by

\footnotetext{
${ }^{2}$ Applied graphics in this paper denotes a role subjected to the manipulative and commercial goals, for example, in daily newspapers, magazines, posters, advertisements, packaging and similar products of the contemporary visual communications and graphic design.
} 
printmaking. Such concept of contemporary teaching is favorable and beneficial, for it awakens the students to their intrinsic capacities. In addition, it improves the student output and stimulates independence in creation of ideas and integration of different approaches. All this affects the discovery and manifestation of creativity in students and their products - graphic prints. In such a dynamic and experiential learning environment, students achieve intellectual and emotional maturity (Costantino, 2011). All forms of contemporary classes are characterized by an effort to teach students how to integrate different concepts and knowledge and to achieve comprehensive understanding of life phenomena. Students who actively participate in such processes are motivated by curiosity and their knowledge is truly based on a full comprehension. Knowledge gained in such a way is permanent and applicable in all life situations" (Čudina-Obradović and Brajković, 2010, 22).

In addition to offering the aforementioned benefits, modern teaching also affects students' social, emotional and aesthetic development (Kyriacou, 1997, Brack, 2009). Therefore, proportionate inclusion of the visual arts (painting, sculpting and printmaking) in art classes, along with specifics of materials and procedures pertaining to each art medium, provides students with greater possibilities for cognitive, psychomotor and emotional development. Such a balanced teaching of arts develops students' creativity, which, in turn, increases flexibility, self-reliance, attention to details, originality of thought and tolerance, as well as planning and production skills. Such form of didactic and methodological approaches ensures that printmaking and other visual arts are equivalent to other subjects in student education (Tacol, 2003).

However, the number of weekly art lessons in Croatian primary schools was cut in half, in accordance with the national plans and programs (HNOS - the Croatian National Educational Standard, 2006). Such reduction in the number of art lessons negatively affects the whole development of students (Hannaford, 2005). To make things worse, the reduction in the number of lessons disables teachers in their delivery of art programs in all their segments, which puts in question the quality of the entire implementation of the prescribed curriculum (Salomon, 2006, Turković, 2009). In other words, this reduction of art lessons from two to one lesson per week negatively affects the aforementioned balance in teaching all fields of art. This has led to the situation in which complex art techniques, including printmaking, have been underrepresented, or even completely left out because the given time frame for holding the classes is simply too short.

The available Croatian literature on printmaking, handbooks for teachers and textbooks for students offer an insight into the standard printmaking techniques, which confirms that the content to be taught and the number of lessons envisaged for holding the classes are in discrepancy. Apart from the reduction in teaching the standard printmaking techniques, insufficient attention has been paid to applied graphics and its role in the formation of consciousness in contemporary society. The Croatian literature about printmaking procedures suitable for students suggests the use of different industrial materials and the application of new and adapted printmaking techniques, auxiliary printmaking techniques and a number of other creative procedures (Grčko, 1970, Hozo, 1988, Jesih, 1988, Planinšek, 2000). Roce (2005) says that non-poisonous materials and household waste can be applied in simple printmaking procedures, in different techniques (relief printing; varnish printing; colography; different methods of printing by using industrial and natural materials; combined use of different types of prints, etc.).

When planning the lessons in printmaking, it is essential to pay attention to the concepts, principles and criteria of contemporary art. However, it is also vital to respect the principles of educational sciences, since art education, contemporary arts and educational sciences are in a dialectic relationship (Karlavaris,1991). It has been noted, however, that the national curriculum and the literature designated for art teaching (teacher handbooks and student textbooks) in Croatia cover only standard printmaking techniques. Even those techniques require more than one art lesson per week. Therefore, it is crucial to explore the contemporary findings in the field of 
printmaking, in order to create conditions to apply those findings. It is necessary to introduce new printmaking techniques to schools, which include new materials, tools and processes. Finally, it is vital to become acquainted to the contemporary context of applied graphics, which has become omnipresent. We should note that the consciousness of today's society is largely influenced by graphic media, primarily in the field of graphic design and visual communications, to which students are constantly exposed. Over-exposedness to the influence of contemporary graphic media significantly affects students' mind and attitudes, which, in turn, may have an adverse impact on the development of students' personality. Kunczik and Zipfel (2006) say that the excessive communication via digital media may result in changes in attitudes and the way of thinking, it can affect knowledge, emotions and general behavior. It is, therefore, vitally important to explore the latest findings in science, education and arts, and finally, printmaking. The national educational programs need to be updated with contemporary graphics and refreshed with new contents. The aim is to raise student awareness and draw their attention to actual contents of the messages conveyed by present-day graphic media.

\section{Problems and objectives of research}

The amount of printmaking lessons in the Croatian primary schools is painfully low, as the result of the aforementioned reduction of art content from two to one lesson per week. Reduction of lessons in printmaking or, worse, their complete elimination due to the limited time frame may negatively affect the acquisition of specific knowledge, competencies and skills related to traditional and contemporary graphics. Moreover, it may adversely affect the whole development of students.

Therefore, the aim of this research was to obtain the latest scientific and professional findings and to deepen the existing knowledge about the importance of printmaking in art education.

The objective was to collect and analyze the attitudes of primary school children about printmaking. We gathered pupils from third, fifth and eighth grades, from three primary schools of Rijeka, Croatia, to express their opinions of printmaking, in these segments:

- Identification of printmaking techniques, concepts and specific printmaking tools

- The frequency of practicing different types of print in regular art education classes

- Active engagement of students in collecting and bringing waste material to printmaking classes

- Attitudes of pupils to "artistic" and "applied" graphics

- Equivalence of printmaking to other fields of art.

We used a specially designed questionnaire to collect, analyze and compare the pupil's attitudes. Pupils responded to the questionnaire before and after the action research, i.e., at the beginning and at the end of a school semester, while the action research itself was carried out in the course of that semester. The plan was to introduce simple, modern printmaking techniques, which are based on the use of available household waste materials. The objectives were the following: to enhance knowledge, experience, skills and competencies in printmaking; to increase pupils' activity and engagement in collecting and bringing waste material to classes and to improve their attitudes about printmaking and its importance in relation to other arts.

\section{Research sample}

The research sample consisted of 170 pupils of third, fifth and eighth grade from three Rijeka's primary schools: "O.Š. Nikola Tesla", "O.Š. Turnić" and "O.Š. Donja Vežica“, which were purposely selected for this research. The first and the second measuring included only those students who took part in the action research. 
The questionnaire was used to gather information about the respondents' gender, grade (third, fifth or eighth grade), grades in Arts and finally, their grade average. Gender ratio was balanced: of 170 respondents, there were 73 (42.9\%) girls and 97 (57.1\%) boys. There were 50 third-grade pupils (29.4\%), 62 fifth-grade pupils (36.5\%), and 58 eighth-grade pupils (34.1\%). The majority of the sample completed the previous school year with the highest grade, i.e., "excellent" $(\mathrm{N}=105(61.8 \%))$. Fifty-eight pupils passed the previous school year with "very good" grade $(34.1 \%)$, while the number of pupils who passed the previous year with lower grades was significantly lower -6 pupils were graded as "good" $(3.5 \%)$ and one student was graded with "sufficient" grade (0.6\%). As for the pupils' grade in Arts, $124(72.9 \%)$ pupils had the highest grade ("excellent"). Forty-one pupils were graded as "very good" (24.1\%), while only few students were graded as "good" $(4(2.4 \%))$ and "sufficient" (1 (0.6\%)). To sum up, pupils who participated in this research had a high grade average, as well as high grades in Arts, which demonstrates the quality of the sample structure.

\section{Methods, instruments and procedures}

The data were obtained by using a questionnaire suitable for pupils of third, fifth and eighth grades. The questionnaire was specially constructed for this research and it consisted of open-ended and close-ended type of questions. Open-ended questions (5) referred to school grade, gender, grade average, grade in Arts and questions referring to the extent to which they prefer Arts as a school subject. Close-ended questions (18) consisted of statements. The pupils responded to the statements by choosing from the following five-point scale: (1) - never, (2) - a little, (3) - sometimes, (4) - often, (5) - always. All of the statements were given in affirmative forms, in accordance with the Likert scale of assessment. In terms of content, the statements explored the following: how often the classes in printmaking were delivered in schools, which printmaking techniques were applied in classes and how often these classes included other, nonstandard printmaking techniques. In addition, they examined how much pupils were familiar with tools and materials used in printmaking, how often pupils brought useful materials to the classes, and finally, they assessed the extent to which pupils consider graphics equal to other fields of art and the extent to which they find it important in the contemporary social context.

The contents of the questionnaire had been tested on six pupils and it was changed afterwards. The objectivity of the questionnaire was achieved by giving consistent, simple and accurate instructions. There was one set of instructions for teachers, and the other set of instructions for the pupils.

The questionnaire reliability was determined by Cronbach alpha. Cronbach alpha was 0.84 , which means that internal consistency of the questionnaire was satisfactory.

The questionnaire was processed by using the following statistical methods: Chi-square test, ttest for dependent variables, one-way analysis of variance (ANOVA) and the Wilcoxon rank sum test. Data analysis and interpretation were done by using the SPSS program for Windows.

\section{Results and discussion}

The comparison of data about the number of pupils who find Arts a "nice subject" in the first and second measuring showed that more than half of the respondents, in both measurings, gave Arts "excellent" grade (92 pupils in the first measuring (54.1\%); 93 pupils in the second measuring (54.7\%)). Nearly a third of the pupils assigned "very good" grade to Arts as a school subject (50 pupils in the first measuring (29.4\%), 53 pupils in the second measuring (31.2\%)), while only few respondents graded the subject with poor grades: there were 4 "sufficient" grades in the first measuring $(2.4 \%), 7$ in the second $(4.1 \%)$; and 3 "insufficient" grades in the first measuring (1.8\%), 5 in the second measuring $(2.9 \%)$. Pupils who perceive arts as a "nice subject" retained such opinion after the action research. Attitudes of pupils who do not find Arts "a nice subject" have not changed either. 
The data indicating a positive perception of Arts as a school subject in primary school children in the County of Primorje and Gorski Kotar are comparable to results of a similar research conducted in the County of Split and Dalmatia, which showed that 56.7 percent of pupils "likes" or "likes a lot" Arts as a school subject (Kušćević et al., 2009).

T-test for dependent variables indicated that there was no statistically significant difference in pupils' grade in Arts in the first and the second measuring. A special comparison of the grades for each class separately also showed that there were no statistically significant differences.

Table 1. Grade average, average grades in Arts and perception of Arts as a "nice subject", in the first and second measuring, for both sexes of the research sample $(\mathrm{N}=170)$

\begin{tabular}{|c|c|c|c|c|c|c|}
\hline Gender & $\begin{array}{l}\text { Grade } \\
\text { average, } 1^{\text {st }} \\
\text { measuring } \\
\text { Ar. mean } \\
\text { (SD) }\end{array}$ & $\begin{array}{l}\text { Grade } \\
\text { average, } 2^{\text {nd }} \\
\text { measuring } \\
\text { Ar. mean } \\
\text { (SD) }\end{array}$ & $\begin{array}{l}\text { Grade in Arts, } \\
1^{\text {st }} \text { measuring } \\
\text { Ar. mean } \\
\text { (SD) }\end{array}$ & $\begin{array}{l}\text { Grade in Arts, } \\
2^{\text {nd }} \\
\text { measuring Ar. } \\
\text { mean (SD) }\end{array}$ & $\begin{array}{l}\text { Perception of } \\
\text { Arts as "nice" } \\
\text { subject, 1st } \\
\text { measuring Ar. } \\
\text { mean (SD) }\end{array}$ & $\begin{array}{l}\text { Perception of } \\
\text { Arts as "nice" } \\
\text { subject, 2nd } \\
\text { measuring Ar. } \\
\text { mean (SD }\end{array}$ \\
\hline Female & $4.66(0.62)$ & $4.81(0.43)$ & $4.81(0.49)$ & $4.92(0.32)$ & $4.52(0.1)$ & $4.51(0.85)$ \\
\hline Male & $4.48(0.68)$ & $4.39(0.63)$ & $4.61(0.56)$ & $4.62(0.56)$ & $4.17(0.95)$ & $4.15(1.01)$ \\
\hline
\end{tabular}

The analysis determined there were statistically significant differences between boys and girls, in both rounds of measuring, in the following aspects:

- Grade average at the end of school year $(\mathrm{M} 1: \mathrm{t}=2.94 ; \mathrm{p}<0,01-\mathrm{M} 2: \mathrm{t}=5.07 ; \mathrm{p}<0.01)$

- Grade in Arts (M1: $\mathrm{t}=4.37$; $<<0.01$ - M2: $\mathrm{t}=4.34 ; \mathrm{p}<0.01$ )

- The extent to which pupils perceive Arts as a "nice subject" (M1: 3.88; $<<0.01-\mathrm{M} 2$ : $\mathrm{t}=2.42 ; \mathrm{p}<0.01$ ).

Generally, girls had a better grade average at the end of school year. The results indicating that girls in lower grades have a better grade average than boys are comparable to results produced by a sociological research (Ilišin et al., 2003). In addition, girls generally had better grades in Arts and showed a greater affinity for this subject as compared to boys. The results of our research indicating that there were differences in school subject preferences regarding pupils' gender and those that indicate that girls liked Arts more than boys are comparable to results obtained in other studies on Arts as a school subject (Rončević, 2009; Pejić Papak et al., 2012).

We did not determine any statistically significant difference between the first and the second measuring, in any of the measured variables (grade average at the end of school year, grade in Arts, perception of Arts as a "nice" subject).

Table 2. Average results in the questionnaire for third-, fifth- and eighth-grade pupils, in the first and the second measuring

\begin{tabular}{l|c|c}
\hline \hline Grade & $\begin{array}{c}\text { Aggregate results of the questionnaire - the first } \\
\text { measuring, Ar. mean (SD) }\end{array}$ & $\begin{array}{c}\text { Aggregate results of the questionnaire - the second } \\
\text { measuring, Ar. mean (SD) }\end{array}$ \\
\hline \multirow{2}{*}{ Third } & $2.44(0.37)$ & $2.95(0.38)$ \\
\cline { 2 - 3 } Fifth & $2.04(0.50)$ & $2.67(0.66)$ \\
Eighth & $246(0.52)$ & $2.88(1.02)$ \\
\hline Total & $\mathbf{2 . 2 9 ( \mathbf { 0 . 5 1 } )}$ & $\mathbf{2 . 8 2}(\mathbf{0 . 7 4})$ \\
\hline \hline
\end{tabular}


T-test for dependent variables determined a statistically significant difference in the average results in the first and the second measuring in terms of how often printmaking techniques were used in classes $(t=7.74: \mathrm{p}<0.01)$. In general, the use of printmaking techniques was significantly higher in the second measuring. Viewed from the aspect of the education level, these differences are also significant:

- Third grades $(\mathrm{t}=7.31 ; \mathrm{p}<0.01)$

- Fifth grades $(\mathrm{t}=6.17 ; \mathrm{p}<0.01)$

- Eighth grades ( $\mathrm{t} 3=2.68 ; \mathrm{p}<0.05)$.

The results of the t-test and great differences in pupils' responses indicate that activity of pupils in the recognition and use of printmaking techniques increased in the second measuring, as did the frequency of the use of different printmaking techniques in Arts classes. Students' knowledge of printmaking and their recognition of printmaking processes also significantly increased in the second measuring.

Results of the questionnaire analysis are presented in the form of medians and ranges. In order to examine the statistical significance of differences we used the Wilcoxon rank sum test.

Table 3. Differences in the questionnaire results referring to the frequency of holding printmaking classes and the use of different printmaking techniques, in third-, fifth- and eighth grade pupils, in the first and the second measuring

\begin{tabular}{|c|c|c|c|c|}
\hline \multirow{2}{*}{\multicolumn{2}{|c|}{$\begin{array}{l}\text { 1. Questions about the frequency of delivering } \\
\text { printmaking classes and the use of different } \\
\text { printmaking techniques }\end{array}$}} & $1^{\text {st }}$ measuring & $2^{\text {nd }}$ measuring & \\
\hline & & M (min-max) & M (min-max) & W (p) \\
\hline 1.1 . & $\begin{array}{l}\text { Frequency of delivering printmaking } \\
\text { classes }\end{array}$ & $2(1-5)$ & $3(1-5)$ & $8.83(.000)$ \\
\hline 1.2 . & $\begin{array}{l}\text { Techniques of creating prints with } \\
\text { artificial and natural materials }\end{array}$ & $2(1-5)$ & $2(1-5)$ & $2.35(.019)$ \\
\hline 1.3 . & $\begin{array}{l}\text { The frequency of use of different } \\
\text { printmaking techniques }\end{array}$ & & & \\
\hline 1.3.1. & Linoleum cut & $1(1-4)$ & $1(1-4)$ & $1.06(.288)$ \\
\hline 1.3.2. & Relief printing & $1(1-5)$ & $2(1-5)$ & $2.36(.018)$ \\
\hline 1.3.3. & Cardboard printing & $2(1-5)$ & $2(1-5)$ & $0.83(.404)$ \\
\hline 1.3.4. & Gravure printing & $1(1-3)$ & $1(1-4)$ & $7.25(.000)$ \\
\hline
\end{tabular}

In the first set of questions, we analyzed the frequency of holding printmaking classes in schools and the frequency of using particular printmaking techniques before and after the action research. In general, the frequency of using particular printmaking techniques has significantly increased in the second measuring (after the research). Further on, results from second measuring point to a more frequent creation of prints using different objects as well as an increased use of different techniques of relief printing. The only exception are techniques that include different items (natural and artificial, such as corkscrew, potato, sponge...), linoleum cut and cardboard printing, where we did not determine any statistically significant increase. This may indicate that regular classes tend to use same techniques for creating prints of different objects and materials every time, and the increase in relief printmaking may be the result of the action research. Apart from the data referring to the frequency of employing different printmaking techniques, we also obtained data that show a significant increase in pupils' recognition and differentiation of printmaking concepts. 
Table 4. Differences in the questionnaire results referring to the use of printmaking tools and machines in third-, fifth- and eighth grade pupils, in the first and the second measuring

\begin{tabular}{|l|l|c|c|c|}
\hline \hline \multirow{2}{*}{$\begin{array}{l}\text { 2. Questions referring to the frequency of } \\
\text { printing and creating matrices and questions } \\
\text { referring to the use of printmaking tools and } \\
\text { machines }\end{array}$} & M (min-max) & M (min-max) & W \\
\cline { 2 - 4 } & W (p) \\
\hline \hline 2.1. & The frequency of printing in classes & $2(1-5)$ & $3(1-5)$ & $6.49(.000)$ \\
\hline 2.2. & The frequency of creating matrices & $1(1-5)$ & $3(1-4)$ & $6.74(.000)$ \\
\hline 2.3. & $\begin{array}{l}\text { The frequency of using specific } \\
\text { printmaking tools }\end{array}$ & & & \\
\hline 2.3 .1$. & Linoleum cutters & $1(1-4)$ & $1(1-5)$ & $3.64(.000)$ \\
\hline 2.3 .2$. & Printing rollers & $1(1-3)$ & $2(1-5)$ & $8.4(.000)$ \\
\hline 2.3 .3$. & Printing press & $1(1-3)$ & $2(1-5)$ & $7.73(.000)$ \\
\hline \hline
\end{tabular}

In the second set of questions, which include those referring to the frequency of printing and creating matrices and those referring to the use of printmaking tools and machines, we found a statistically significant increase.

Table 5. Differences in the questionnaire results relating to collection and use of waste materials in classes, in third-, fifth- and eighth grade pupils, in the first and the second measuring

\begin{tabular}{|c|c|c|c|c|}
\hline \multirow{2}{*}{\multicolumn{2}{|c|}{$\begin{array}{l}\text { 3. Questions referring to pupils' collection and } \\
\text { use of waste materials in art classes }\end{array}$}} & \multirow{2}{*}{$\frac{1^{\text {st }} \text { measuring }}{\mathbf{M}(\mathbf{m i n}-\mathbf{m a x})}$} & \multirow{2}{*}{$\frac{2^{\text {nd }} \text { measuring }}{\mathbf{M} \text { (min-max) }}$} & \multirow[b]{2}{*}{ W (p) } \\
\hline & & & & \\
\hline 3.1 . & $\begin{array}{l}\text { Frequency of collecting and bringing } \\
\text { waste materials to art classes }\end{array}$ & $3(1-5)$ & $3(1-5)$ & $2.08(.005)$ \\
\hline 3.2 . & $\begin{array}{l}\text { Frequency of using household waste } \\
\text { materials in art classes }\end{array}$ & $3(1-5)$ & $3(1-5)$ & $4.65(.000)$ \\
\hline 3.3 . & $\begin{array}{l}\text { Pleasure in using household waste } \\
\text { materials in art classes }\end{array}$ & $3(1-5)$ & $4(1-5)$ & $1.73(.083)$ \\
\hline 3.4 . & $\begin{array}{l}\text { Frequency of using household waste } \\
\text { materials in printmaking processes }\end{array}$ & $1(1-5)$ & $3(1-5)$ & $8.20(.000)$ \\
\hline
\end{tabular}

The third set of questions was related to pupils' activity in collecting and bringing waste materials to art classes. Frequency of collecting and bringing available household waste to art classes (cardboard, old rags, newspapers, jute bags, yogurt and pate lids, aluminum foils etc.) increased after the action research. The frequency of using waste materials in printmaking processes also increased, as well as the pupils' satisfaction in applying such materials in their work. We may reach the conclusion that teachers in the action research motivated students and encouraged them to find and bring household waste materials to the classes, which might positively affect the pupils' awareness of waste and its reuse. 
Table 6. Differences in the questionnaire results referring to the recognition of artistic and applied graphics, in third-, fifth- and eighth grade pupils, in the first and the second measuring

\begin{tabular}{|c|c|c|c|c|}
\hline \multirow{2}{*}{\multicolumn{2}{|c|}{$\begin{array}{l}\text { 4. Questions referring to the recognition and } \\
\text { differentiation of artistic and applied } \\
\text { graphics }\end{array}$}} & $1^{\text {st }}$ measuring & $2^{\text {nd }}$ measuring & \multirow{3}{*}{$\frac{\mathrm{W}(\mathrm{p})}{1.06(.139)}$} \\
\hline & & $\mathrm{M}(\min -\max )$ & M (min-max) & \\
\hline 1 & Recognition of graphics in everyday life & $5(1-5)$ & $4(1-5)$ & \\
\hline 2 & $\begin{array}{l}\text { Pupils' opinion about importance of } \\
\text { graphics }\end{array}$ & $4(1-5)$ & $4(1-5)$ & $2.16(.031)$ \\
\hline 3 & $\begin{array}{l}\text { Attitudes about equivalence of artistic } \\
\text { graphics to other areas of art }\end{array}$ & $4(1-5)$ & $4(1-5)$ & $0.99(.324)$ \\
\hline
\end{tabular}

Finally, set of questions relating to attitudes about applied graphics demonstrate that there was a statistically significant change and that the pupils' attitudes about the importance of applied graphics improved after the action research. We should note that the prevailing answers to this set of questions were "often" or "always". Further, the pupils find original (artistic) graphics as important as any other field of art and they found its correlations with contemporary, applied graphics. It was obvious that the pupils had developed artistic and visual sensibility and that they had acquired basic knowledge referring to differences between artistic and applied graphics, but we should also emphasize that their visual sensibility slightly increased in the second measuring.

\section{Conclusion}

The analysis of the questionnaire administered before and after the action research clearly indicated that the research produced a positive effect on the quality of printmaking classes.

It was determined that $54.7 \%$ of the pupils think Arts is "a nice subject". Girls more prefer Arts as a school subject, they generally have a better grade average at the end of school year, and they have better grades in Arts, as compared to boys.

The research showed that there was a statistically significant increase in the pupils' recognition of printmaking techniques, concepts and specific printmaking tools in the second measuring, thanks to the increased employment of printmaking techniques after the action research.

There was also an increase in recognition and differentiation of concepts in printmaking technologies and types of print.

The second measuring showed a wider variety in applying printmaking techniques and working with different types of prints. For instance, there was an elevated use of printmaking press, while standard printmaking techniques, such as creating prints with different artificial and natural materials, as well as linoleum and cardboard printing, were less frequently used.

Teachers' encouragement of pupil activity throughout the action research produced positive effects. After the research, the pupils became more active in collecting and bringing waste materials to art classes. This also influenced the pupils' awareness of personal engagement in classes, as well as the awareness about the possibilities of reusing waste materials. Importantly, the pupils showed satisfaction in working with such materials.

Finally, after the action research, the pupils had a better opinion about printmaking in general. It may be concluded that a positive change occurred in the pupils' attitudes about the importance of graphics in today's world. Their perception of applied graphics and its difference from the original graphics also improved and they find original, artistic graphics as important as any other field of art. This points to a higher level of recognition and appreciation of arts in general. 


\section{References}

1. Andrilović V., Čudina M. (1985). Psihologija učenja i nastave. Zagreb: Školska knjiga.

2. Beal N., Bley Miller G. (2001). The Art of Teaching Art to Children: In School and at Home. NewYork: Farrar, Straus and Giroux.

3. Brack, J.C. (2009). Učenjem do pokreta, kretanjem do spoznaje! Program senzomotoričkih aktivnosti za djecu predškolske dobi. Buševec: Ostvarenje.

4. Brešan D. (2004). Sloboda mašte neopterećene tehnikom. Grafika, hrvatski časopis za umjetničku grafiku i nakladništvo, 2(3), 85.

5. Costantino, T. (2011). Researching Creative Learning: A review essay. International Journal of Education \& the Arts, 12(7), http://www.ijea.org/v12r7/. pregl. 7.05.2012.

6. Čudina- Obradović, M., Brajković S. (2010). Integrirano poučavanje. Zagreb: Biblioteka korak po korak.

7. Evans, W. Tokarczyk, J.R., Mccray, S., Source, A. (2002). Block scheduling: An evaluation of outcomes and impact. Clearing House, 75(6), 319-323.

8. Grčko, S. (1970). Grafički postupci u osnovnoj školi. Pedagoška akademija u Rijeci.

9. Hannaford C. (2005). Smart Moves: Why Learning isn Not All in Your Head. Arlington: Great River Books.

10. HNOS, Nastavni plan i program za osnovnu školu (2006), Ministarstvo znanosti, obrazovanja i športa. Zagreb: Gipa.

11. Hozo, DŽ. (1988). Umjetnost multioriginala. Kultura grafičkog lista. Ljubljana: Prva književna komuna Mostar.

12. Ilišin, V., Mendeš, I., Potočnik D. (2003). Politike prema mladima u obrazovanju i zapošljavanju. Politička misao, 11(3), 58-89.

13. Jelavić, F. (1998). Didaktika. Jastrebarsko: Naklada Slap.

14. Jesih, B. (1988). Grafične tehnike visokega tiska. Likovna vzgoja, april/maj, 13-17.

15. Karlavaris, B. (1991). Metodika likovnog odgoja 2. Rijeka: Hofbauer.

16. Karlavaris, B., Kraguljac, M. (1981). Razvijanje kreativnosti putem likovnog vaspitanja u osnovnoj školi. Institut za pedagoška istraživanja. Beograd: Prosveta.

17. Kunczik, M., Zipfel, A. (2006). Uvod u znanost o medijima i komunikologiju, Zagreb: Zaklada Friedrich Ebert.

18. Kušćević, D., Brajčić, M., Mišurac Zorica, I. (2009). Stavovi učenika osmih razreda osnovne škole o nastavnom predmetu likovna kultura. Školski vjesnik, 58(2), 189-198.

19. Kyriacou, C. (1997). Temeljna nastavna umijeća: metodički priručnik za uspješno poučavanje i učenje. Zagreb: Educa.

20. Montessori, M. (2003). Dijete. Tajna djetinjstva. Jastrebarsko: Naklada Slap.

21. Pejić Papak, P., Vidulin-Orbanić, S., Rončević, A. (2012). Uloga organiziranih aktivnosti u kulturnom životu učenika. Život i škola, 2(28), 188-203.

22. Planinšek V. N. (2000). Linogravura. Likovna vzgoja. Junij-julij, 34-36.

23. Roce, B. (2005). 30 za 30 od Novalje do Novigrada, 20 godina grafike u školi stvaralaštva. Rijeka: Škola stvaralaštva „Novigradsko proljeće“, katalog.

24. Rončević, A. (2009). Multimedia in primary school. Doktorska disertacija. Ljubljana: Pedagoška fakulteta.

25. Ross J.,Romano C., Ross T. (1990). The complete printmaker. New York: The Free Press.

26. Salamon, J. (2006). HNOS i likovna umjetnost. Kvartal, kronika povijesti umjetnosti u Hrvatskoj, 3(4), 2-5.

27. Tacol, T. (2010). Od načrtovanja učnega procesa likovnega snovanja do refleksije. Priročnik za pouk Likovno snovanje. Ljubljana: Pedagoška fakulteta.

28. Turković, V. (2009). Umjetničko obrazovanje u tranziciji: Likovno obrazovanje u europskom obrazovnom sustavu. Metodika 18, 10(1), 8-38.

29. Watts, R. (2005). Attitudes to making art in the primary school. Journal compilation, 24(3), 243-253. 